\title{
Molecular and Cellular Actions of Platelet-activating Factor in Rat Heart Cells
}

Clara V. Massey," Trudy A. Kohout," Shirley T. Gaa, ${ }^{*}$ W. J. Lederer," and Terry B. Rogers*\|

Departments of ${ }^{*}$ Medicine, Division of Cardiology, ${ }^{\ddagger}$ Biological Chemistry, ${ }^{8}$ Physiology, and Medical Biotechnology Center, University of Maryland School of Medicine, Baltimore, Maryland 21201

\begin{abstract}
Platelet-activating factor (PAF) is a phospholipid with cardiovascular actions at low concentrations (1-100 nM) but with uncertain direct myocardial actions. We investigated the cellular and molecular effects of PAF on heart cells using isolated adult and neonatal rat myocytes. Addition of PAF, in the superfusion solution, decreased twitch amplitude and contractile velocity in both systems. Concentrations of PAF below 1 nM stimulated reproducible responses with maximal effects seen at $100 \mathrm{nM}$. These functional actions of PAF could be blocked by the known PAF antagonist, BN 50739, in a dose-dependent manner. Parallel biochemical studies showed that nanomolar PAF rapidly stimulated the phosphoinositide pathway in cultured myocytes, evidenced by the accumulation of $\left[{ }^{3} \mathbf{H}\right]$ inositol phosphates in prelabeled cultured myocytes. The potency and specificity of PAF, as well as the time course, for the response were nearly identical in the biochemical and functional assays. PAF produced no functional changes in protein kinase $\mathbf{C}$-depleted myocytes, but it did stimulate inositol trisphosphate accumulation in such cells. We conclude that: (a) PAF exerts a direct negative inotropic effect on myocardial tissue; (b) the effects of PAF are mediated by a specific, high affinity cardiac receptor; $(c)$ an underlying biochemical mechanism for the action of PAF includes the activation of the phospholipase $\mathrm{C}$ / phosphatidylinositol intracellular signaling pathway, which leads to activation of protein kinase C. (J. Clin. Invest. 1991. 88:2106-2116.) Key words: cardiac $\bullet$ myocytes $\bullet$ inotrope $\bullet$ receptor • phosphoinositide
\end{abstract}

\section{Introduction}

Platelet-activating factor $\left(\mathrm{PAF}^{1}, 1-O\right.$-alkyl-2-acetyl-sn-glycero3-phosphorylcholine) is a potent signaling molecule whose biological activity was initially associated with platelet activation $(1,2)$. This phospholipid is now known to have profound ef-

Portions of this work were presented at the American Heart Association Scientific Meetings, 12-15 November 1990, Dallas, TX.

Address correspondence to Dr. Terry B. Rogers, Department of Biological Chemistry, University of Maryland School of Medicine, 660 West Redwood Street, Baltimore, MD 21201.

Received for publication 6 November 1990 and in revised form 8 July 1991.

1. Abbreviations used in this paper: Ins $(1,4,5) \mathrm{P}_{3}$, inositol-1,4,5-trisphosphate; InsP $\mathrm{P}_{2}$, inositol bisphosphate; InsP, inositol monophosphate; InsP $\mathrm{P}_{3}$, inositol trisphosphate; PAF, platelet-activating factor; TPA, 12-O-tetradecanoylphorbol-13-acetatephorbolester.

J. Clin. Invest.

(c) The American Society for Clinical Investigation, Inc.

$0021-9738 / 91 / 12 / 2106 / 11 \$ 2.00$

Volume 88, December 1991, 2106-2116 fects on many tissues including muscle cells, vascular tissue, and neurons (3-5). PAF can be synthesized in and released from many tissues including kidney, lung, and heart, as well as from cells in the circulation in response to appropriate stimuli $(3,6-8)$. Biochemical investigation into the biosynthesis of PAF indicates that heart muscle could be exposed to this molecule in a physiological setting. In this regard, recent studies have reported that significant quantities of PAF were measured in coronary effluent after an ischemic intervention $(9,10)$.

Despite this evidence, there has been confusion concerning the action of PAF on cardiac tissue. In recent studies, PAF has been reported to have little or no direct action on the myocardium $(10,11)$. It was proposed that the cardioactive effects of PAF arise secondarily to platelet-dependent release of cardioactive agents (thromboxane $\mathrm{A}_{2}$, histamine, and leukotrienes). In contrast, in earlier studies using electrically paced isolated cardiac tissue, a case was made for direct action of PAF on the heart $(12,13)$. Detailed information concerning the action of this phospholipid in cardiac cells has been limited by the complex tissue and cellular systems used in these experiments.

In this study isolated adult and neonatal rat heart cells were used to investigate the actions of PAF on a cardiac tissue uncomplicated by other cell types. We report here that PAF exerts a direct negative inotropic effect on such cells and that this effect is mediated by a specific cardiac PAF receptor. Furthermore, we suggest that the functional changes in heart cells produced by PAF arise from the activation of protein kinase $C$ via the phospholipase $\mathrm{C} /$ phosphatidylinositol intracellular signaling pathway.

\section{Methods}

Preparation of cardiac myocytes. Isolated single cells from adult rat cardiac ventricular tissue were prepared by enzymatic disaggregation of the intact tissues. The cells were placed in a four-well $1.7-\mathrm{cm}$ culture dish. After $30 \mathrm{~min}$ the cells settled to the bottom of the plate and were used the same day (14). Spontaneously beating primary cultures of neonatal rat cardiac ventricular myocytes were prepared from 1-d old Sprague-Dawley rats (15). The cells were plated in four-well $1.7-\mathrm{cm}$ tissue culture dishes and grown in culture for 4-5 d (15-17).

Measurement of contractile properties of adult or neonatal cells. Contractions of single cardiac myocytes, in four-well culture dishes, were measured using an optical video dimension analysis system as previously described (15). Briefly, the four-well culture dish was mounted on the stage of an inverted phase microscope and the cells in a single well were superfused at $1 \mathrm{ml} / \mathrm{min}$ with control medium (DME, $25 \mathrm{mM}$ Hepes, $0.25 \% \mathrm{BSA}, \mathrm{pH} 7.3$ ) equilibrated with $95 \% \mathrm{O}_{2}-5 \% \mathrm{CO}_{2}$ at $32^{\circ} \mathrm{C}$. After a 10 -min equilibration period, the cells were superfused with control medium containing various compounds as indicated in Results. When the cells were electrically driven $40-\mathrm{V}$ pulses of $10 \mathrm{~ms}$ duration were used. PAF was added to the superfusion buffers from stock solutions in dimethylsulfoxide, such that the medium contained a final dimethylsulfoxide concentration of $0.1 \%$. Control experiments indicated that this concentration of vehicle had no effect on contractile behavior. The image of the beating cells was monitored using a video 
camera (Cohu Inc., San Diego, CA) and the video signal was recorded on tape. The motion of the cell wall was measured with the use of a video dimension analyzer (Instrumentation for Physiology \& Medicine; San Diego, CA) during the experiment and off-line. The video dimension analyzer identifies the cell edge by contrast transition and tracks the edge as its position changes during contraction. A voltage proportional to cell shortening is produced by the analyzer, recorded, and then analyzed using an IBM PC compatible computer. The contraction and relaxation velocities were obtained mathematically by differentiating the position versus time output of the video dimension analyzer.

Loading conditions for contraction caused by attachment of the cell to the cover slip or to other cells may vary from cell to cell. However, by expressing the contractile response of the cell as a percentage of the basal response, these differences in loading conditions are taken into account and each cell can serve as its own control.

Measurement of inositol phosphates. Cells in culture (4-5 d old) were labeled with $10 \mu \mathrm{Ci} / \mathrm{ml}$ of $\left[{ }^{3} \mathrm{H}\right]$ myo-inositol for $24 \mathrm{~h}$ in serum-free DME-Hepes, $0.25 \%$ BSA, unless otherwise indicated. Pilot studies revealed that the absence of serum during the labeling phase had no qualitative effects on the biochemical or biological responses reported in Results. However, serum-free media greatly improved the signal in the assay. At the time of the experiment the cells were washed with 4 $\times 0.5 \mathrm{ml}$ DME-Hepes, $0.25 \% \mathrm{BSA}$, and treated as indicated in Results. After aspirating the supernatant, the reaction was stopped by rapidly adding $0.5 \mathrm{ml}$ of $6 \%$ perchloric acid at $0^{\circ} \mathrm{C}$. The acid extract was neutralized and the $\left[{ }^{3} \mathrm{H}\right]$ inositol phosphates were resolved using ion exchange chromatography as described previously $(15)$. Total $\left[{ }^{3} \mathrm{H}\right]$ inositol phosphates were collected by eluting them from the columns with 3 $\mathrm{ml}$ of $2 \mathrm{M}$ ammonium formate/0.1 $\mathrm{M}$ formic acid. In some experiments only the $\left[{ }^{3} \mathrm{H}\right]$ inositol bisphosphate $\left(\mathrm{Ins}_{2}\right)$ fraction was collected since its signal provided the largest accumulation over basal.

Materials. The following substances were obtained from Sigma Chemical Co., St. Louis, MO: DME-Hepes; PAF; lyso-PAF (L- $\alpha-$ lysophosphatidylcholine, $\gamma$-O-alkyl); formic acid; ammonium formate; TPA (12-O-tetradecanoylphorbol-13-acetatephorbolester). Perchloric acid was obtained from J. T. Baker Chemical Co., Phillipsburg, NJ). $M y o-\left[2-{ }^{3} \mathrm{H}(N)\right]$-inositol and $\left[{ }^{3} \mathrm{H}\right] \operatorname{Ins}(1,4,5) \mathrm{P}_{3}$ were from NEN Research Products, Wilmington, DE. Dowex AGI-X8 (formate form) was from Bio-Rad Laboratories, Rockville Center, NY. The following companies kindly supplied these PAF antagonists: BN 52021 and BN
50739, Institut Henri Beaufour, Le Plessis Robinson, France; Brotizolam and WEB 2086, Boehringer Ingelheim Pharmaceuticals Inc., Ridgefield, CT; Ro 19-3704/001, Hoffmann-LaRoche Inc., Nutley, NJ; SRI 63-441, Sandoz Research Institute, E. Hanover, NJ.

\section{Results}

PAF has diverse actions on cardiac and smooth muscle as well as on nerves. It has been shown to reduce myocardial contractile force $(12,18-20)$ and has been proposed as a promotor of ischemia-reperfusion injury by both direct and indirect action (21-23). It is not clear if PAF-mediated cardiac abnormalities result from direct actions of this substance on heart cells or from indirect actions such as reduced blood flow, altered neuronal input to the myocardium, or platelet activation with subsequent release of secondary mediators. Initial experiments were designed to determine if PAF had any direct effects on cardiac tissue free of these potentially confounding factors. Accordingly, we examined the responses of isolated cardiac myocytes after application of PAF. We used both acutely isolated adult cardiac cells and cultured neonatal myocytes. Myocytes, acutely dissociated from adult rat ventricle, were placed in a superfusion chamber, driven electrically at 90 beats per min, and then exposed to 200 nM PAF. As shown in Fig. 1, application of PAF resulted in a decrease in beating amplitude and a decrease in the maximum velocities of contraction and relaxation. In the signal-averaged responses, the overall shape of the twitch and waveform for the contraction/relaxation velocities were not altered by PAF treatment. This result is from a representative experiment. The results from several experiments with separate preparations indicate that PAF decreased twitch amplitude by $22 \pm 15 \%(n=3)$. These results demonstrate that PAF can decrease contractility in a cardiac cell preparation that is not complicated by neuronal, platelet, or hemodynamic effects.

We complemented these studies by examining the effects of PAF in cultures of spontaneously beating neonatal rat ventricu-

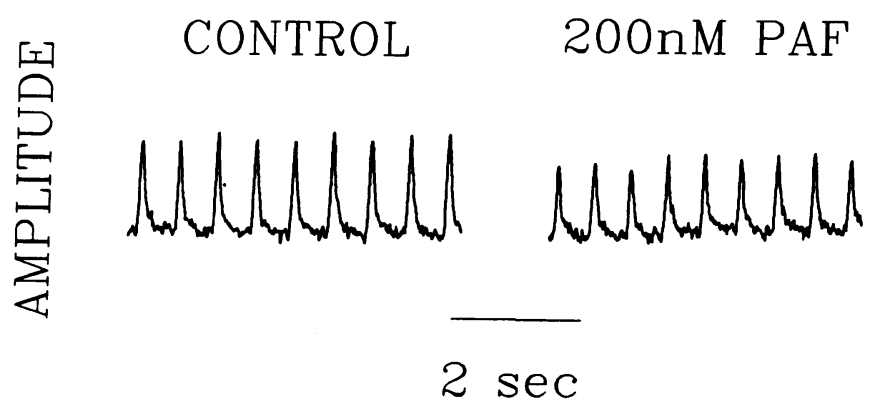

\section{AVERAGE}
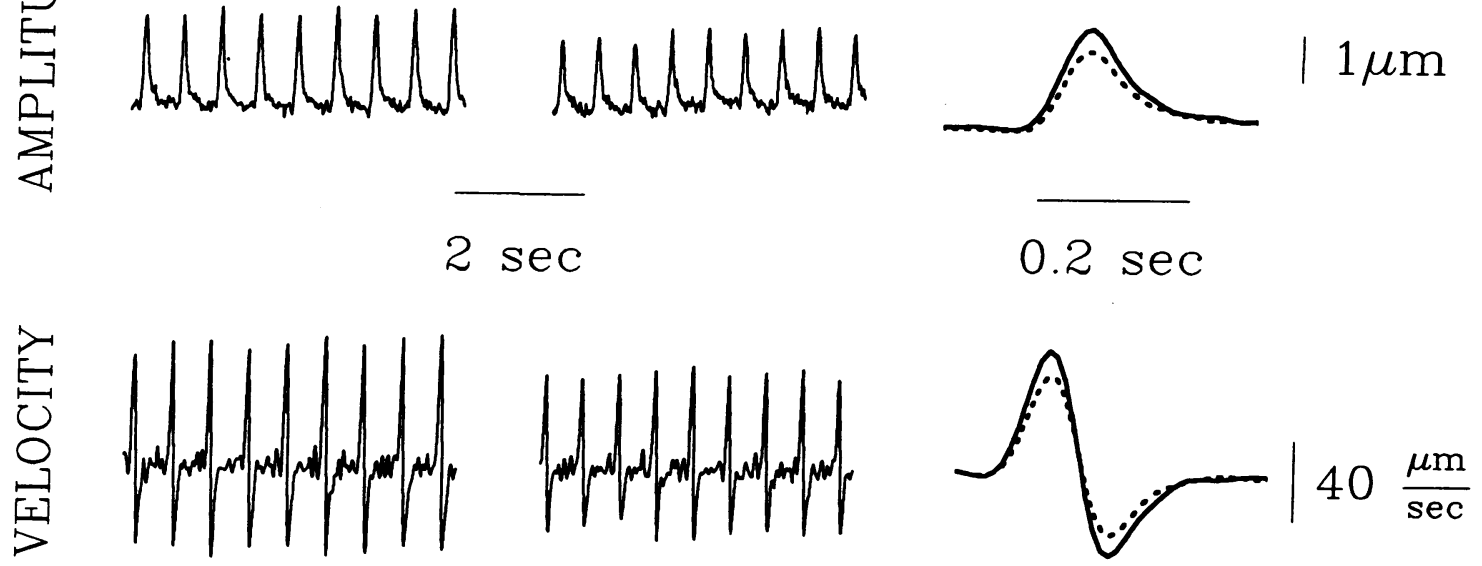

Figure 1. Effects of PAF on contractile behavior of dissociated adult rat ventricular myocytes. Isolated myocytes were superfused with DMEHepes, $0.25 \%$ BSA, and field stimulated with $40-\mathrm{V}$ pulses of $10 \mathrm{~ms}$ duration at 90 pulses per min. The contractile behavior was monitored by the use of an optical video dimension analysis system. Shown is the beating record from a typical cell under control conditions and 6 min after application of $200 \mathrm{nM}$ PAF. Shown on the right are the signal-averaged twitches and cell shortening velocity curves from the same data under control conditions (solid line) and after exposure to PAF (dotted line). 
lar myocytes. This well defined cardiac preparation allows for molecular and functional studies to be performed in parallel (15-17). Fig. 2 shows that spontaneously contracting heart cells superfused with $80 \mathrm{nM}$ PAF exhibited a rapid increase in the beating rate (66\% over $2 \mathrm{~min})$. Decreases in amplitude (50\%) and in maximum contraction/relaxation velocities were also observed in this representative experiment. The addition of PAF in several experiments showed an average maximal increase in spontaneous beating rate of $72 \pm 5.4 \%$ above control values (mean \pm SEM, $n=7$ ). The average decrease in amplitude was $39 \pm 4.6 \%$ below control values (mean $\pm \operatorname{SEM}, n=7$ ).

Since it is possible that the PAF-mediated decreases in both velocity and amplitude result from the increases in contractile frequency, the action of PAF on myocytes at a fixed frequency was investigated. Fig. 3 shows that when myocytes were electrically driven at 90 beats per min, application of $20 \mathrm{nM}$ and 80 $\mathrm{nM}$ PAF resulted in a rapid decrease in twitch amplitude. The results from a series of experiments revealed that $20 \mathrm{nM}$ and 80 $\mathrm{nM}$ PAF decreased twitch amplitude by $32 \pm 6.3 \%$ and $24 \pm 8.8 \%$, respectively (mean $\pm \operatorname{SEM}, n=5-6$ ), values which are not statistically different. Fig. 3 also shows that the overall shape of the twitch is not altered by $80 \mathrm{nM}$ PAF. These results demonstrate that the effects of PAF on electrically driven neonatal myocytes are similar to the responses observed in adult heart cells. However, the negative inotropic effects of PAF are reduced in paced neonatal cells compared to spontaneous beating neonatal myocytes. Taken together, these data suggest that some of the action of PAF is rate related, but the negative inotropic effects of PAF cannot be explained on the basis of rate change alone.

To investigate the possibility that the functional responses we have observed are receptor mediated, the potency and speci- ficity of the PAF effects were characterized. The effects of PAF on both frequency and amplitude were dose dependent. As shown in Fig. 4, PAF was very potent in evoking functional responses, with $1 \mathrm{nM}$ PAF increasing frequency by $>20 \%$ over control. The dose-response relation was biphasic, with an initial phase between $0.5 \mathrm{nM}$ and $20 \mathrm{nM}$ and a second phase between $20 \mathrm{nM}$ and $100 \mathrm{nM}$. Contractile amplitude in the second phase decreased by up to $65 \%$. Fig. 5 shows that the biologically inactive analogue of PAF, lyso-PAF, had no effect on contractile behavior, even at concentrations as high as $100 \mathrm{nM}$.

The specificity of the PAF-evoked effects was further examined by the use of a potent PAF receptor antagonist, BN 50739 (24). Before application of $20 \mathrm{nM}$ PAF, cells were pretreated with various concentrations of BN 50739 for $10 \mathrm{~min}$. As shown in Fig. 6, BN 50739 was very potent in blocking the functional responses of the cells to PAF, with half-maximal doses in the 10 $\mathrm{nM}$ range. If the inhibitory effects of BN 50739 are due to its action at the level of the receptor, then the inhibition should be competitive in character. To test this hypothesis, a PAF doseresponse curve was generated in the presence of a half-maximal dose of BN 50739 (10 nM). As shown in Fig. 7, addition of BN 50739 caused a displacement of the PAF dose-response curve to the right by about one order of magnitude, without altering the maximal response of the cells at high doses of PAF. These results support the view that PAF and BN 50739 compete for a common receptor site. Taken together, they indicate that there is a specific cardiac PAF receptor that mediates the negative inotropic action of this phospholipid.

These results suggest that there are specific PAF-receptor mediated intracellular molecular mechanisms that underlie the potent biological effects of PAF on cardiac myocytes. The functional responses evoked by PAF, decreases in twitch am-
CONTROL

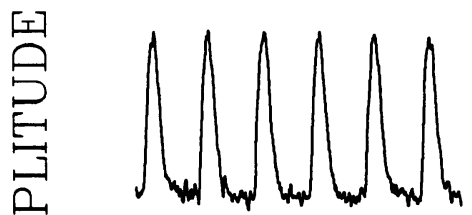

$\overline{2 \sec }$
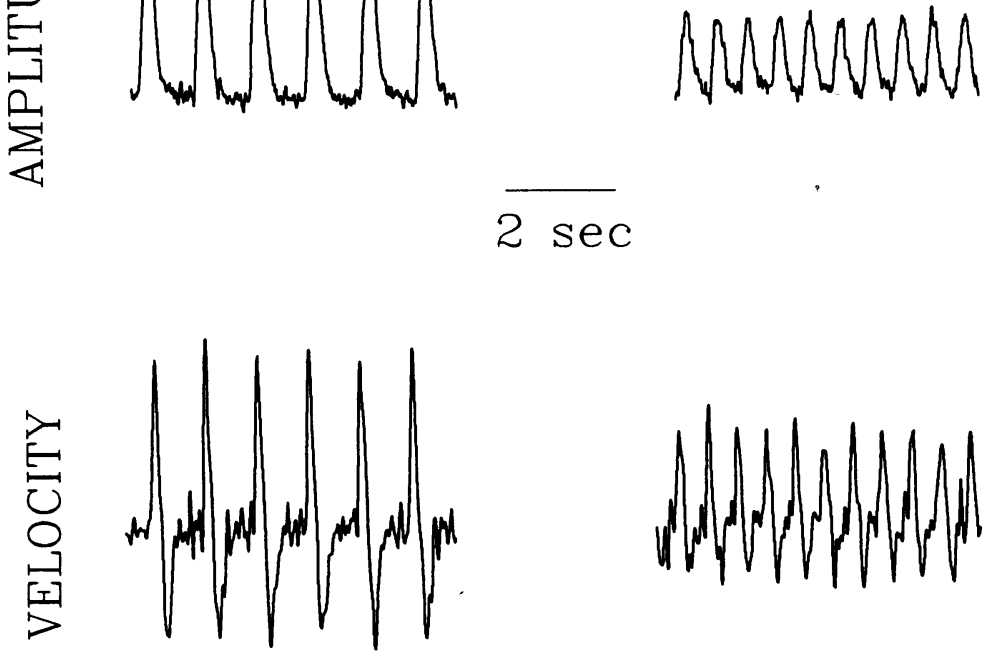

AVERAGE
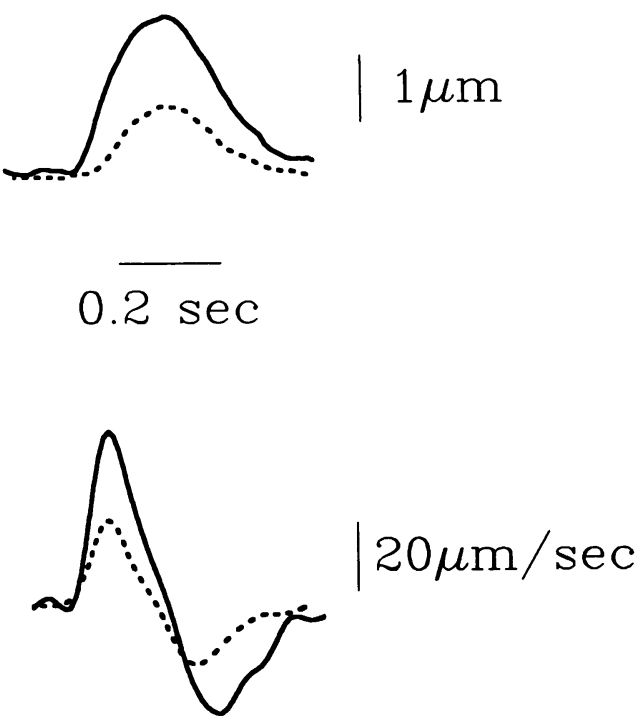

Figure 2. Effects of PAF on contractile behavior of spontaneously beating cultured neonatal rat ventricular myocytes. Cultured neonatal myocytes were superfused with control medium and the spontaneous beating behavior was recorded. The superfusion solution was switched to control medium containing $80 \mathrm{nM}$ PAF and the changes in spontaneous beating behavior were monitored. Shown are the responses in a typical experiment under control conditions and $3 \mathrm{~min}$ after exposure to PAF. On the right are the signal-averaged twitches and cell shortening velocity curves under control conditions (solid line) and after exposure to PAF (dotted line). 

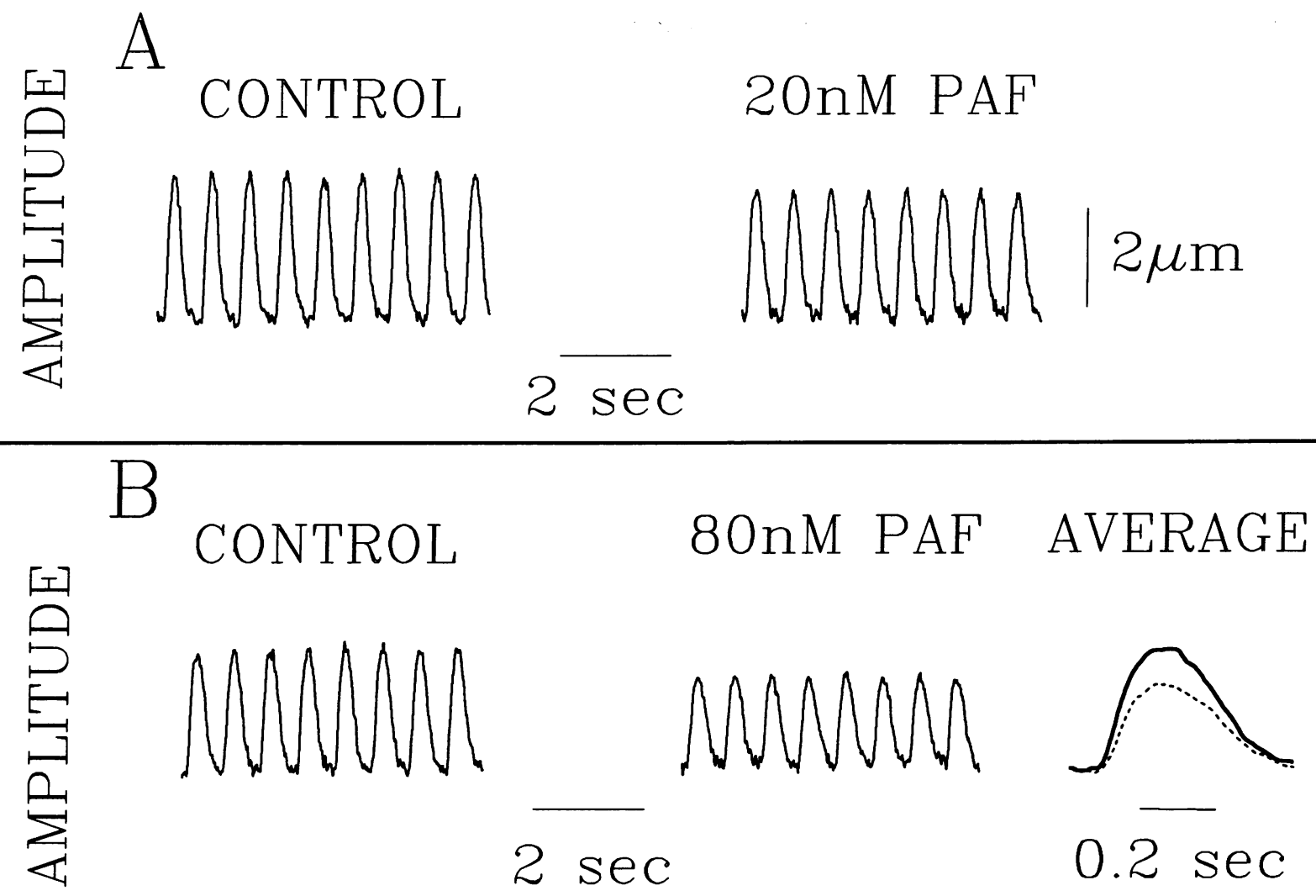

Figure 3. Effects of PAF on the contractile behavior of electrically driven cultured neonatal rat ventricular myocytes. Cultured cells (intrinsic spontaneous beating rate $40-70$ beats per min) were field stimulated with $40-\mathrm{V}$ pulses of $10 \mathrm{~ms}$ duration at a constant rate of 90 pulses per min. After an equilibration period either $20 \mathrm{nM}$ PAF $(A)$ or $80 \mathrm{nM}$ PAF $(B)$ were added to the superfusate. Shown are typical responses after 3-min exposures to PAF. On the right side of $B$ the signal-averaged twitches under control conditions (solid line) and after exposure to $80 \mathrm{nM}$ PAF (dotted line) are shown.

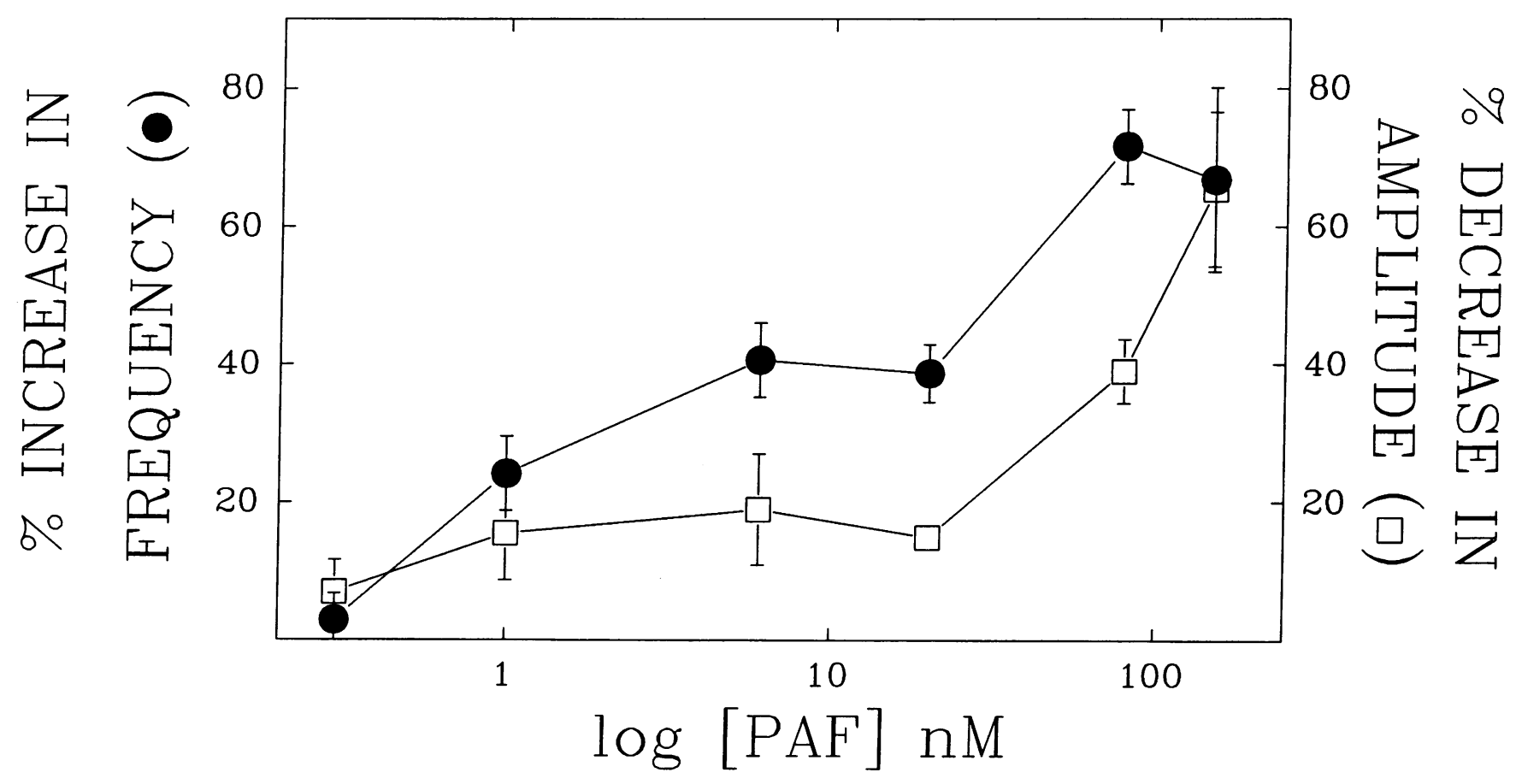

Figure 4. Dose-response relation for PAF effects on contractile behavior of spontaneously beating cultured neonatal rat ventricular myocytes. The initial beating behavior of cultured cells was assessed in cells that were superfused with control medium. The superfusate was switched to control medium supplemented with a range of PAF concentrations and the resulting beating behavior was recorded. The results are reported as percent change relative to the initial, pre-PAF, values for frequency (๑) and amplitude ( $\square$ ). The data points are the means \pm SEM from four to nine separate experiments. 


\section{CONTROL $\quad$ 100nM LYSO-PAF}
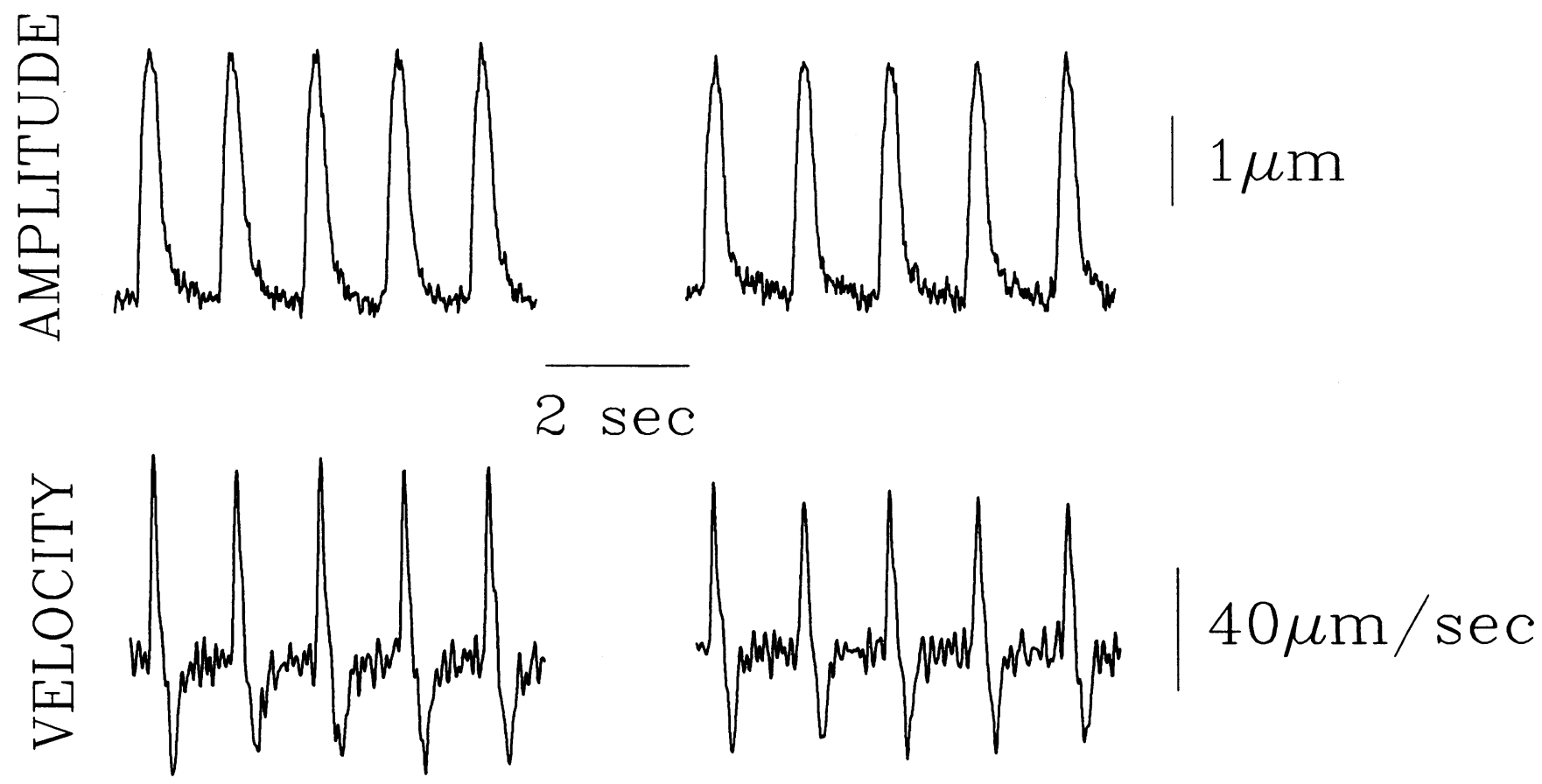

Figure 5. Effects of lyso-PAF on contractile behavior of spontaneously beating cultured neonatal rat ventricular myocytes. After the cells were equilibrated in control medium, the superfusate was switched to control medium supplemented with $100 \mathrm{nM}$ lyso-PAF. Shown is a representative beating record of a cell under control conditions and $4 \mathrm{~min}$ after application of lyso-PAF. This agent produced no changes in contractile behavior in three separate experiments.

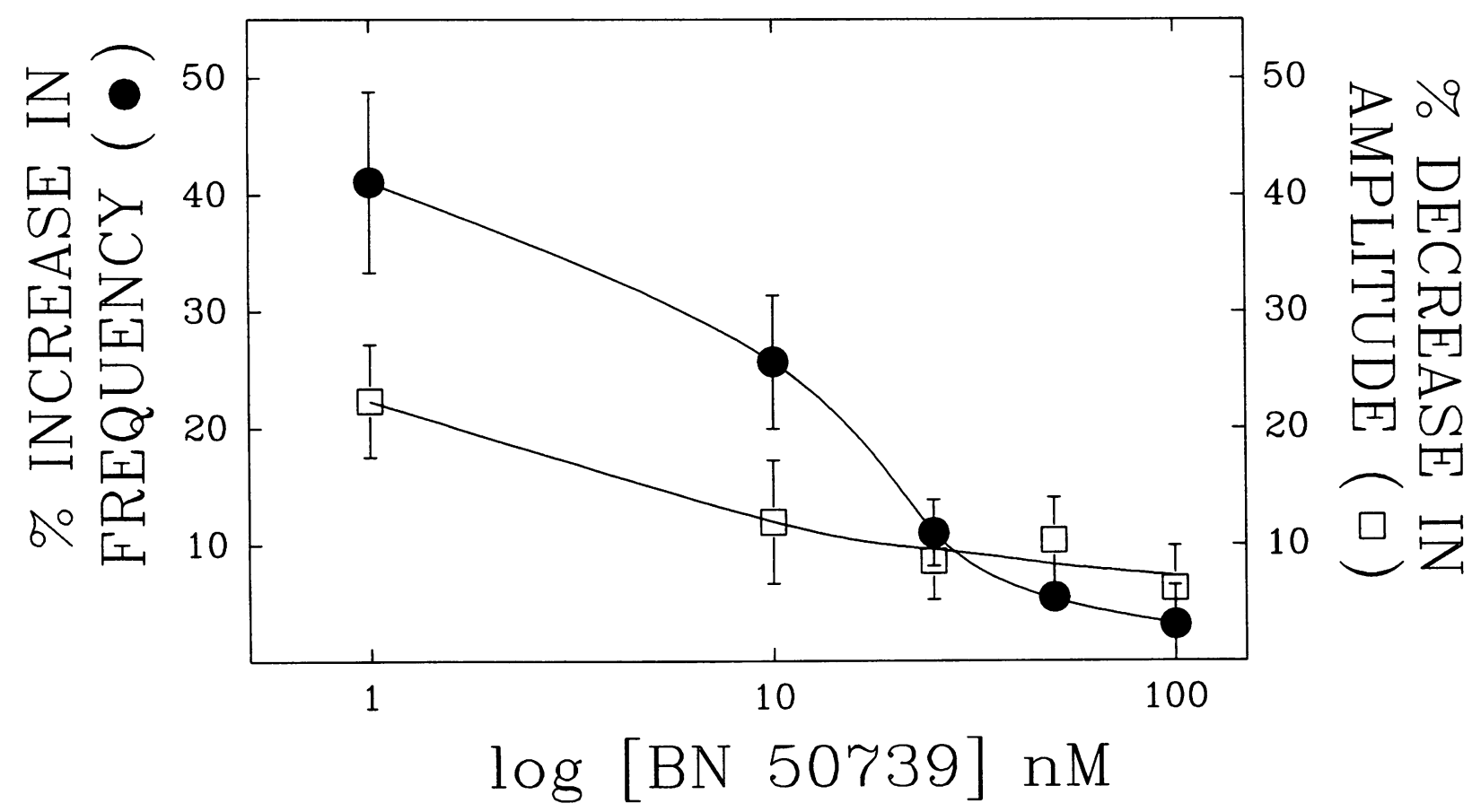

Figure 6. Effect of PAF antagonist, BN 50739, on the PAF-induced functional responses of cultured neonatal rat ventricular myocytes. Spontaneously contracting cultures were superfused with medium containing various concentrations of BN 50739 for 6 min. The superfusate was switched to medium containing the same concentration of BN 50739 supplemented with $25 \mathrm{nM}$ PAF. The changes in beating frequency (๑) and twitch amplitude () after a 3-min exposure to PAF are shown relative to the initial values. The data points are the means \pm SEM from four to eight separate experiments. 


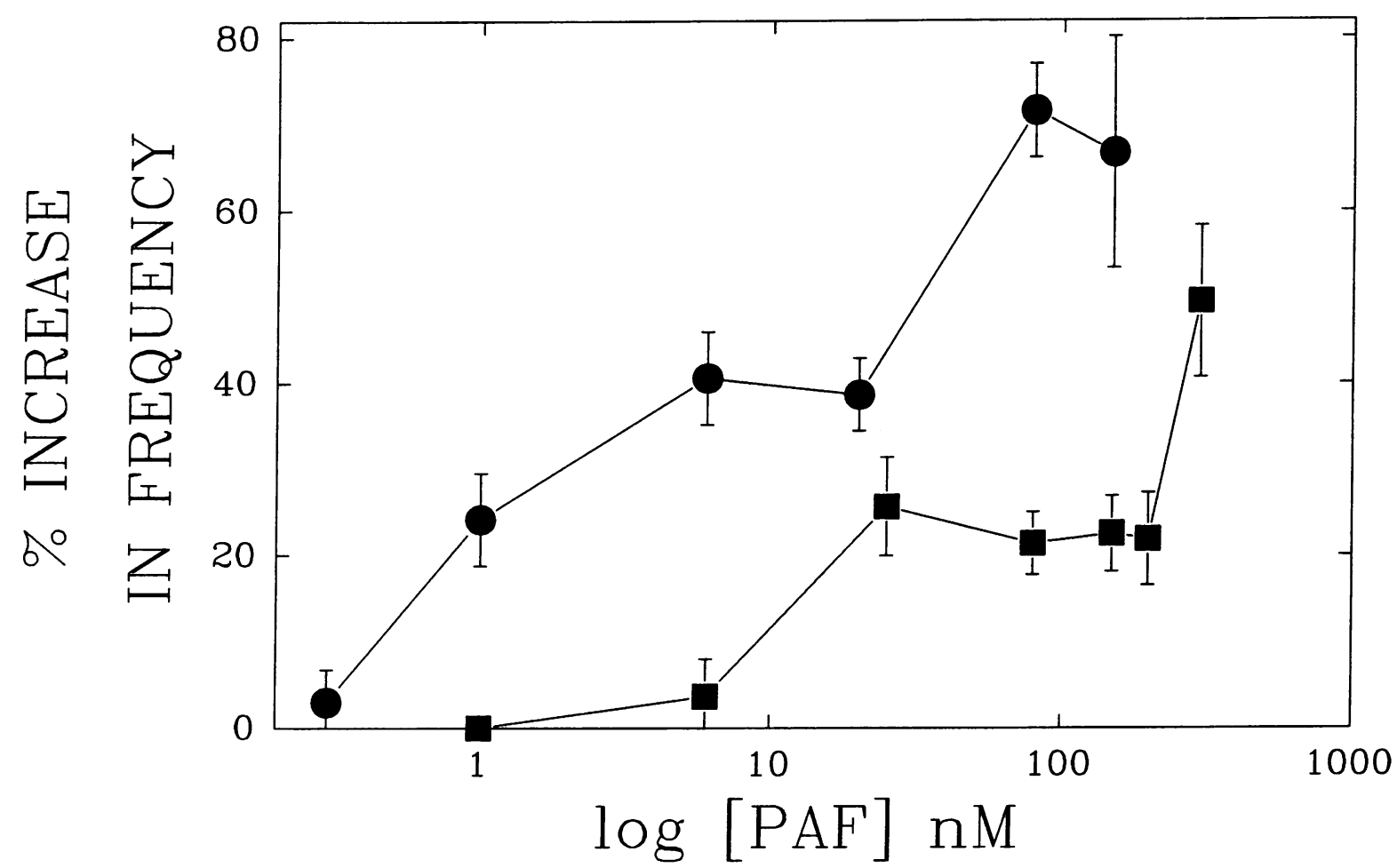

Figure 7. Effects of BN 50739 on the PAF dose-response relation in spontaneously beating cultured neonatal rat ventricular myocytes. A doseresponse curve for the functional effects of PAF on spontaneous beating behavior was measured as described in Fig. 4 except that the superfusate was switched to control medium with PAF plus $10 \mathrm{nM}$ BN 50739. Shown are the PAF dose-response curves for media containing PAF (•) or media containing PAF supplemented with $10 \mathrm{nM}$ BN 50739 (๘). The data are the means of three to eight separate experiments \pm SEM.

plitude and increases in frequency, are analogous to those observed for angiotensin II. This hormone stimulates the phosphoinositide signaling pathway in these cultures (15). Accordingly, experiments were designed that would test the hypothesis that PAF activates the same signaling pathway. Myocytes that had been prelabeled with $\left[{ }^{3} \mathrm{H}\right]$ inositol were exposed to $25 \mathrm{nM}$ PAF and the resulting production of $\left[{ }^{3} \mathrm{H}\right]$ inositol phosphates was quantitated. As shown in Fig. 8, time course studies revealed that application of PAF resulted in the rapid accumulation of $\left[{ }^{3} \mathrm{H}\right]$ inositol monophosphate (InsP), $\left[{ }^{3} \mathrm{H}\right] \mathrm{Ins} \mathrm{P}_{2}$, and $\left[{ }^{3} \mathrm{H}\right]$ inositol trisphosphate $\left(\operatorname{Ins}_{3}\right)$. Maximal values for $\left[{ }^{3} \mathrm{H}\right]-$ Ins $\mathrm{P}_{2}$ and $\left[{ }^{3} \mathrm{H}\right]$ Ins $\mathrm{P}_{3}$ of 1 .7-fold stimulation over basal and 3fold stimulation over basal, respectively, were noted at $2 \mathrm{~min}$. Thus the time course for phosphoinositide turnover is comparable to the rate of onset of the functional responses evoked by PAF.

Taken together, these results suggest that activation of phosphoinositide turnover is an underlying mechanism for the action of PAF on cardiac cells. This hypothesis was tested by examining the potency and specificity of PAF in stimulating this signaling pathway. PAF evoked a dose-dependent accumulation of $\left[{ }^{3} \mathrm{H}\right]$ inositol phosphates over a 2 -min interval as shown in Fig. 9. PAF was very potent in stimulating $\left[{ }^{3} \mathrm{H}\right] \mathrm{InsP}$ and $\left[{ }^{3} \mathrm{H}\right]$ Ins $\mathrm{P}_{2}$ accumulation with half-maximal concentrations in the range of $5 \mathrm{nM}$. Maximal responses were obtained at a dose of $20 \mathrm{nM}$. Thus, the threshold and effective concentrations of PAF in both the biochemical and functional experiments are very similar.

Other experiments were performed to further explore the specificity of the action of PAF. The biologically inactive analogue, lyso-PAF, did not increase the accumulation of $\left[{ }^{3} \mathrm{H}\right]-$ inositol phosphates at a concentration of $25 \mathrm{nM}$ (data not shown). Since the specific PAF antagonist, BN 50739, is a potent inhibitor of the functional responses of cardiac myocytes to PAF, its effects on PAF-evoked phosphoinositide turnover were examined. As shown in Fig. 10, when cells were preincubated with BN 50739 before the application of PAF, the antagonist blocked the subsequent PAF-evoked accumulation of $\left[{ }^{3} \mathrm{H}\right]$ Ins $\mathrm{P}_{2}$ in a dose-dependent manner. This agent was very potent, with an $\mathrm{IC}_{50}$ in the range of $5 \mathrm{nM}$. Thus, the antagonist potency of BN 50739 was comparable in both the biochemical and functional assays.

These data support the view that PAF-evoked biochemical and physiological responses are mediated by a specific, high affinity receptor. Since the possibility of multiple receptors has been raised (25), an important issue arises concerning the pharmacological characteristics of the cardiac receptor. Measurements of phosphoinositide turnover were employed to characterize the pharmacology of the cardiac PAF receptor by using the inhibitory potencies of different PAF antagonists as an index of their affinities for the PAF receptor. As shown in Fig. 10, BN 50739 was most potent and SRI 63-441 was about 10-fold less potent $\left(\mathrm{IC}_{50} \approx 50 \mathrm{nM}\right)$. Brotizolam, RO 19-3704/001, and WEB 2086 were also less potent with ${ } \mathrm{IC}_{50}$ 's in the range of 100-300 nM. The ginkgolide antagonist, BN 52021, was not an effective blocker, even at doses of $1 \mu \mathrm{M}$ (data not shown). The rank order of potency of these drugs is consistent with the relative affinities of these antagonists for the PAF receptor in platelets (26). This demonstrates that: $(a)$ there are potent antagonists of the cardiac PAF receptor; and $(b)$ the pharmacology of the cardiac PAF receptor is similar to that characterized in platelets.

The results presented above suggest that a second messenger derived from the phosphoinositide pathway mediates the 

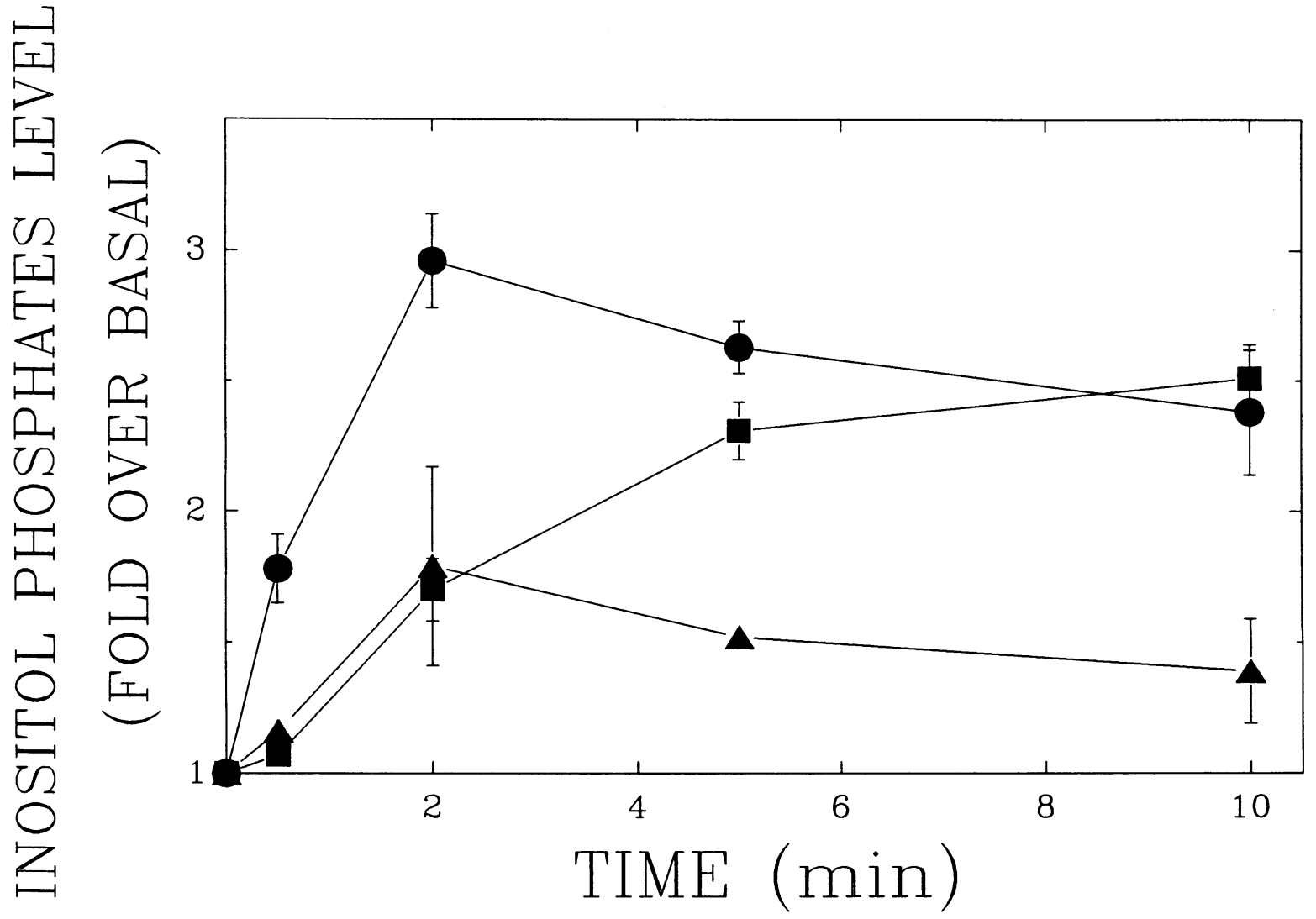

Figure 8. Time course of PAF-stimulated release of inositol phosphates in cultured neonatal rat ventricular myocytes. Cultured myocytes were prelabeled with $\left[{ }^{3} \mathrm{H}\right]$ inositol and then incubated with $25 \mathrm{nM}$ PAF for increasing time periods. After incubation, the level of intracellular $\left[{ }^{3} \mathrm{H}\right]$ inositol phosphates was determined from cell extracts. Shown are the time course curves for $\left[{ }^{3} \mathrm{H}\right] \operatorname{Ins} \mathbf{P}(\bullet),\left[{ }^{3} \mathrm{H}\right] \operatorname{Ins} \mathrm{P}_{\mathbf{2}}(\bullet)$, and $\left[{ }^{3} \mathrm{H}\right] \operatorname{Ins} \mathrm{P}_{\mathbf{3}}(\boldsymbol{\Delta})$. The results are reported as fold-stimulation over basal. Basal values were obtained in parallel cultures incubated in the absence of PAF. These values were: $\left[{ }^{3} \mathrm{H}\right] \mathrm{InsP}, 200 \mathrm{cpm} ;\left[{ }^{3} \mathrm{H}\right] \mathrm{Ins} \mathrm{P}_{2}, 30 \mathrm{cpm}$; and $\left[{ }^{3} \mathrm{H}\right] \mathrm{Ins} \mathrm{P}_{3}, 65 \mathrm{cpm}$. The data points are the means of three experiments, each performed in duplicate, \pm SEM.

functional responses of PAF. Further, the responses to PAF are similar to those with agents that are known to stimulate protein kinase $C$ in these cultures $(15,16)$. To examine the hypothesis that protein kinase $\mathrm{C}$ mediates the effects of PAF, experiments were designed using cells that were depleted of this enzyme. Myocytes were treated overnight with the phorbol ester, TPA $(1 \mu \mathrm{M})$. We have previously shown that in neonatal myocytes under these conditions there is $>96 \%$ loss of enzyme activity (17). These cultures were exposed to $25 \mathrm{nM}$ PAF, a dose that maximally stimulated phosphoinositide turnover. As shown in Fig. 11, PAF did not evoke functional changes in these cells; application of $25 \mathrm{nM}$ PAF had no effect on either the frequency ( 34 beats per $\mathrm{min}$ ) or the amplitude of contraction. The signalaveraged twitches underscore the lack of response of protein kinase C-depleted cells to PAF. The failure of such cells to respond to PAF might result from a lack of a phosphoinositide response. However, as shown in Fig. 12, PAF stimulated the production of inositol phosphates in protein kinase $\mathrm{C}$-depleted cells in a manner analogous to that in normal cells. These data support the conclusion that protein kinase $C$, rather than Ins $(1,4,5) \mathrm{P}_{3}$, is an important mediator of the effects of PAF on cardiac cells.

\section{Discussion}

The ability of PAF to adversely affect cardiac function has been well documented in the literature $(3,27)$. Yet the physiological importance of this phospholipid in cardiac disease has been difficult to establish due to the complex experimental models used. For example, administration of exogenous PAF to laboratory animals leads to cardiac dysfunction $(18-20,28)$. However, this agent alters vascular tone, activates the sympathetic nervous system, and stimulates most cells of the systemic circulation $(3,7,8,27)$. Thus, it is difficult to delineate specific cardiac effects in such models.

Other experimental evidence implicates PAF alterations in cardiac function. PAF receptor antagonists are protective in models of myocardial ischemia $(4,22,23)$. More focused experiments with paced isolated human atrial tissue and guinea pig papillary muscle suggest that PAF has a direct negative inotropic effect $(12,13)$. Yet, other recent experiments have been interpreted to suggest that the effects of PAF on heart depend on platelet activation and release of secondary mediators $(10,11)$. Thus, it is clear that other approaches are required in order to define the role of PAF in cardiac function and disease.

It was within this context that we initiated studies to examine the effects of PAF in isolated rat ventricular myocytes: a simplified cell system that contains no vascular, neuronal, or blood components. The principal findings of this report are: $(a)$ PAF exerts a direct negative inotropic effect on myocardial tissue; $(b)$ the effects of PAF are mediated by a specific, high affinity receptor located on myocardial cells; $(c)$ an underlying 


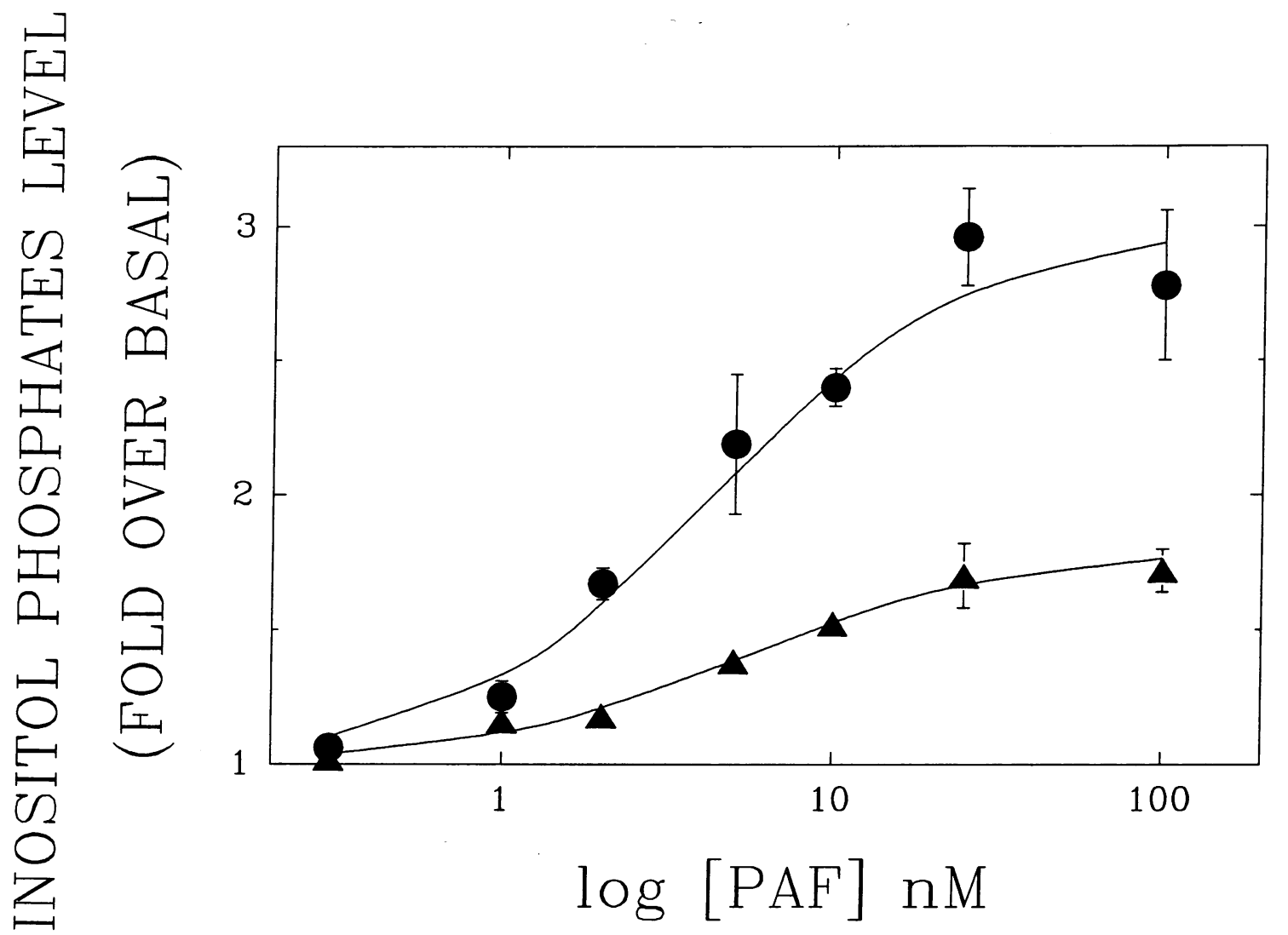

Figure 9. Dose-response curves for the PAF-stimulated release of inositol phosphates. $\left.{ }^{3} \mathrm{H}\right]$ Inositol-prelabeled cultures were incubated with a range of PAF concentrations for 2-min intervals. After the incubations, the levels of $\left[{ }^{3} \mathrm{H}\right] \operatorname{InsP}(\Delta)$ and $\left[{ }^{3} \mathrm{H}\right] \operatorname{Ins} \mathrm{P}_{2}(\bullet)$ were determined from cell extracts. The data points represent the means of three experiments, each performed in duplicate, \pm SEM. When the error bars are not seen they do not extend beyond the size of the symbol.

biochemical mechanism for the action of PAF includes the activation of the phospholipase C/phosphatidylinositol/protein kinase $C$ intracellular signaling pathway; and $(d)$ cultured neonatal rat myocytes represent a valid and useful model for investigating the myocardial actions of PAF and its antagonists.

Negative inotropic effects of PAF. The initial studies were performed in electrically stimulated dissociated adult rat myocytes. PAF evoked a decrease in myocardial contractility characterized by a decrease in beating amplitude, velocity of contraction, and velocity of relaxation. Having documented a direct negative inotropic effect in adult cells, subsequent experiments were performed in cultures of spontaneously beating neonatal rat myocytes. Here the functional studies produced results analogous to the responses observed in adult cells; decreases in beating amplitude, velocity of contraction, and velocity of relaxation.

In the spontaneously beating neonatal cell preparation, PAF also evoked a rapid increase in the beating frequency. It could be argued that in this cell system the PAF-mediated fall in myocardial contractility was the result of increased contractile frequency. However, when neonatal cells were electrically driven at a fixed rate, decreases in amplitude, velocity of contraction, and velocity of relaxation comparable to those observed in the adult cell preparation were still noted. Although part of the response in neonatal cells may be rate related, these results reveal that PAF is a negative inotropic agent in both isolated adult and neonatal rat ventricular cells.
Characterization of a cardiac $P A F$ receptor. A conclusion from the data reported here is that the effects of PAF are mediated by a specific, high affinity receptor located on cultured myocytes. PAF is potent in evoking cardiac responses, with threshold doses in the $1 \mathrm{nM}$ range. Further, the effects of PAF on contractile behavior are dose-dependent and saturable, in respect to both frequency and amplitude. The dose-response relation was biphasic with an initial phase between 0.5 and 20 $\mathrm{nM}$ and a second phase between 20 and $100 \mathrm{nM}$. The doses seen in the initial phase are consistent with recent measurements of PAF in the circulation. PAF concentrations have been seen to increase from undetectable levels to $0.6-2 \mathrm{nM}$ in two separate models: $(a)$ in coronary effluent of isolated rabbit heart during initial reperfusion following an ischemic intervention; $(b)$ in coronary sinus samples of patients with coronary artery disease undergoing atrial pacing $(9,10)$. These data underscore the physiological relevance of the PAF-evoked responses reported here.

Examination of the specificity of the PAF effects provided further evidence for a cardiac receptor. The biologically inactive analogue of PAF, lyso-PAF, had no effect on contractile behavior. BN 50739, a potent synthetic PAF receptor antagonist (24), blocked the effects of PAF in a dose-dependent manner, with half maximal doses in the nanomolar range. Finally, experiments performed in the presence of a half-maximal dose of BN 50739 caused a displacement of the PAF dose-response curve to the right, without altering the maximal response to agonist. These results support the view that PAF and BN 50739 


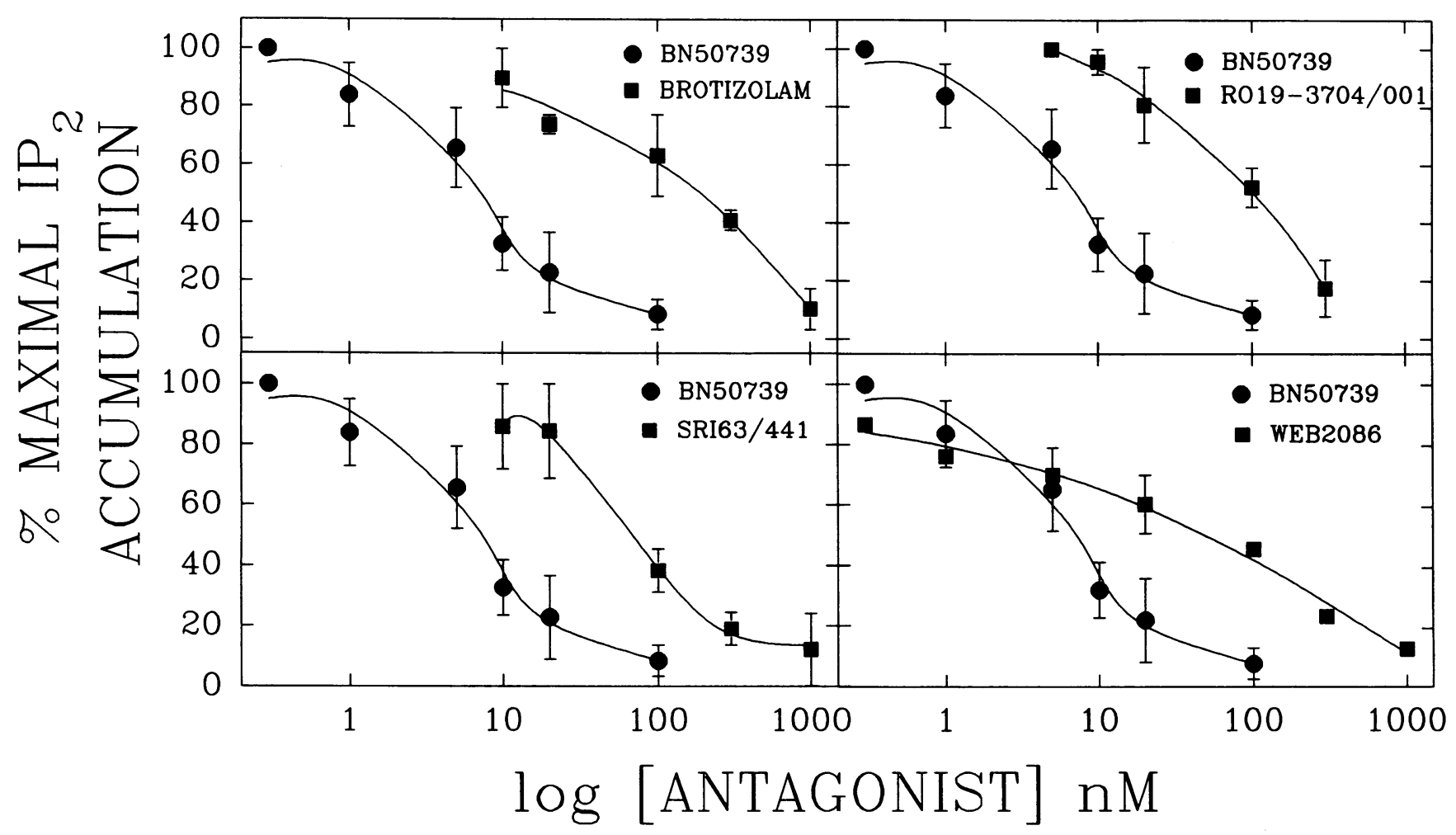

Figure 10. Dose-response curves for PAF antagonists. $\left[{ }^{3} \mathrm{H}\right] \mathrm{Inositol-prelabeled} \mathrm{cultures} \mathrm{were} \mathrm{incubated} \mathrm{for} 6$ min at $37^{\circ} \mathrm{C}$ with the $\mathrm{PAF}$ antagonists. After this preincubation, $25 \mathrm{nM}$ PAF was applied to the cultures for $2 \mathrm{~min}$ and the levels of $\left.{ }^{3} \mathrm{H}\right] \mathrm{Ins} \mathrm{P}_{2}$ were measured. The results are reported as percent maximal values which were obtained in parallel experiments in which antagonists were not included. The curve for the most potent antagonist, BN 50739 (๑), is shown in each panel for comparison. The curves for the other antagonists ( () are labeled in each panel. The data points are the means from at least three experiments \pm SEM.

compete for a common receptor site. Taken together, they indicate that the negative inotropic effects of PAF are mediated by a specific cardiac PAF receptor.

Molecular mechanism for action of PAF. A major goal of this investigation was to explore the underlying molecular mechanisms responsible for the effects of PAF on myocardial cells. In multiple experiments reported here, application of low doses of PAF resulted in a rapid accumulation of inositol phosphates. Thus, PAF stimulates the phosphoinositide pathway in cardiac cells. This finding is consistent with previous reports of PAF-evoked phosphoinositide activation in platelets and other tissues $(8,29)$.

It was important to determine if the PAF-evoked activation of the phosphoinositide pathway underlies the observed functional responses. Indirect evidence strongly supports this conclusion. First, PAF evoked a dose-dependent accumulation of inositol phosphates with threshold and maximal concentrations comparable to those seen in the high affinity response observed in the functional studies. Second, the time course for PAF-mediated inositol phosphates accumulation is comparable with the rate of onset of PAF-evoked functional responses. Finally, the potent PAF receptor antagonist, BN 50739, blocked PAF-stimulated inositol phosphates accumulation in a dose-dependent manner, with a half maximal inhibitory dose comparable to that observed in the functional experiments. Taken together, these results are consistent with the view that the high affinity PAF-evoked responses are mediated, in part, by the phosphoinositide pathway. This also suggests that the responses of myocytes to doses of PAF in the 50-100 nM range are mediated by other additional mechanisms.
There are two important second messengers produced in the phosphoinositide pathway, Ins $(1,4,5) \mathrm{P}_{3}$, and 1,2-diacylglycerol. The latter activates protein kinase $C$. Ins $(1,4,5) \mathrm{P}_{3}$ mobilizes $\mathrm{Ca}^{2+}$ in many cells but there is disagreement concerning its role in cardiac cells (30-32). In contrast, there is considerable evidence that protein kinase $\mathrm{C}$ activation results in negative inotropic responses in a variety of cardiac tissues, including human heart $(16,33-35)$. The functional studies reported here suggest that the effects of PAF are mediated by protein kinase $C$ because the effects noted are identical to those seen in previous studies with angiotensin II and phorbol esters $(15,16)$. Both of these agents are known activators of protein kinase $C$. More direct studies with protein kinase $\mathrm{C}$-depleted cells revealed that PAF failed to produce functional changes in the absence of this enzyme. It is not likely that the depletion protocol damaged the cells since several results that we have previously reported indicate that these myocytes function normally. The phosphoinositide responses to angiotensin II and $\alpha$-adrenergic receptor stimulation are completely normal in these cells (36). Further, the expression and function of sarcoplasmic reticulum, a target for protein kinase $C$, is not altered when compared to control cells (17). Finally, in the present study PAF still activated the receptor-mediated phospholipase $C$ pathway in depleted cells, demonstrated by the accumulation of inositol phosphates, including $\operatorname{Ins}(1,4,5) P_{3}$. These data dissociate Ins $(1,4,5) \mathrm{P}_{3}$ production from the PAF-evoked functional effects and define an important role for protein kinase $C$ in mediating the effects of PAF on heart cells.

Characterization of cardioactive PAF antagonists. There is evidence for multiple receptors for PAF in several cells (25). 
CONTROL

空
PKC DEPLETED

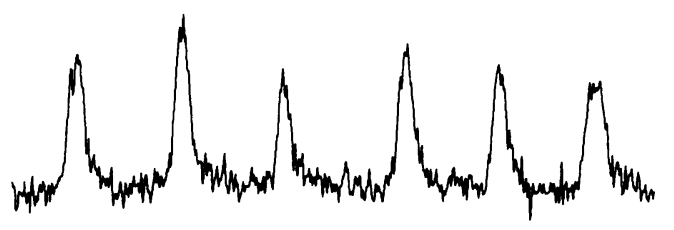

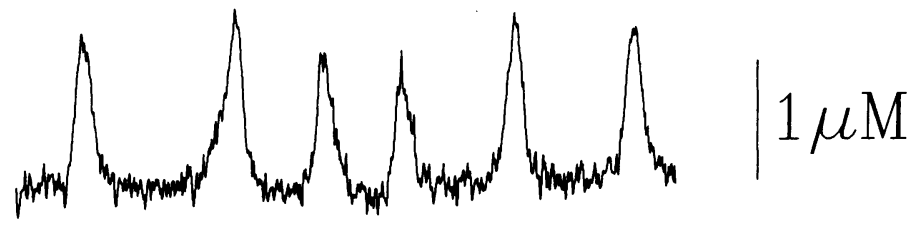

$1 \mathrm{sec}$

\section{SIGNAL AVERAGE}

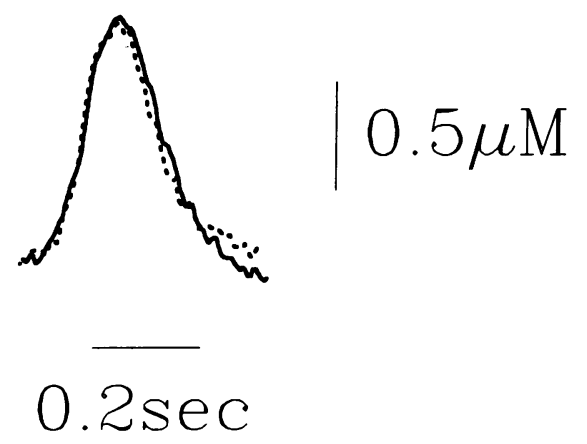

Figure 11. Functional effects of PAF on protein kinase C-depleted cells. Cultured neonatal rat ventricular myocytes were incubated with $1 \mu \mathrm{M}$ TPA overnight to reduce protein kinase $C$ activity. The enzyme-depleted cultures were superfused with control medium and the spontaneous beating behavior was recorded. The superfusate was switched to control medium containing $25 \mathrm{nM}$ PAF and the resulting beating behavior was recorded. Shown is the beating record of a cell under control conditions and $2 \mathrm{~min}$ after exposure to PAF. Displayed below are the signal-averaged twitches derived from the same data under control conditions (solid line) and after exposure to PAF (dotted line).
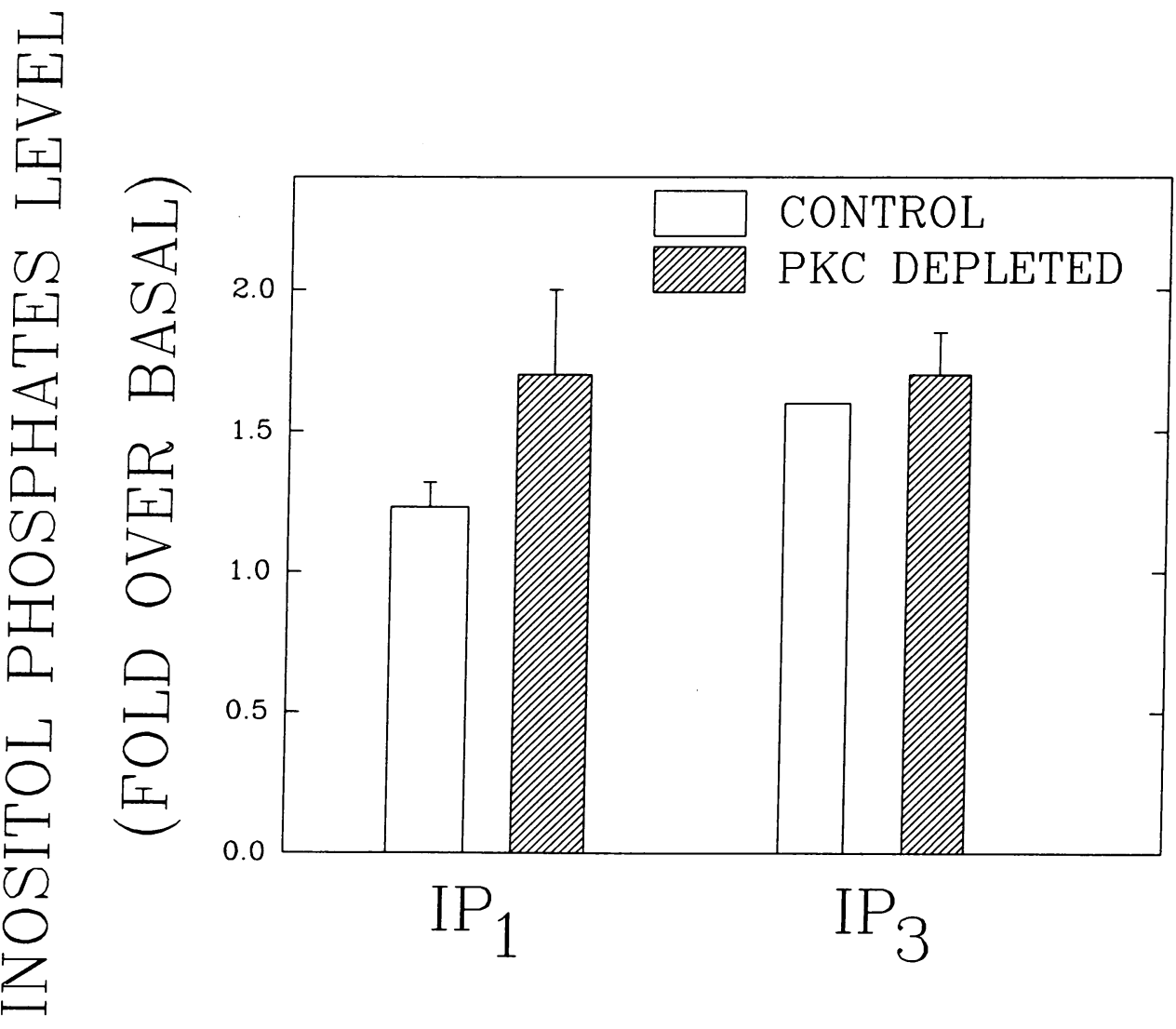

Figure 12. PAF-stimulated release of inositol phosphates in protein kinase $C$-depleted cells. Protein kinase C-depleted cultures (hatched bars) or control cells (open bars) were exposed to $25 \mathrm{nM}$ PAF for $2 \mathrm{~min}$. The levels of $\left[{ }^{3} \mathrm{H}\right]$ Ins $\mathrm{P}$ and $\left[{ }^{3} \mathrm{H}\right]$ Ins $\mathrm{P}_{3}$ were determined as described in Fig. 8. The data points represent the means of three experiments, each performed in duplicate, \pm SEM. 
Thus, it was important to further characterize the pharmacological features of the cardiac PAF receptor. Measurements of phosphoinositide turnover were used to assess the potency of six known PAF antagonists as an index of their affinities for the receptor. The rank order of potency we noted in cardiac tissue is consistent with the relative affinities of these drugs for the PAF receptor in platelets, demonstrating that the cardiac receptor is similar pharmacologically to that observed in platelets (26). Thus, this cell system can be used to evaluate the relative potency and potential cardiac efficacy of a variety of PAF antagonists.

In summary, the present results demonstrate that PAF decreases contractile behavior and increases phosphoinositide turnover in isolated rat ventricular myocytes. These effects are mediated by a specific cardiac PAF receptor which ultimately leads to the activation of protein kinase $C$. The receptor appears to be similar to that which has been identified in other tissues. Finally, with a potential role for PAF antagonists in the treatment of ischemia-reperfusion injury, this cultured cell system provides a valuable tool for assessing the relative efficacy of these antagonists.

\section{Acknowledgments}

We thank Dr. Giora Feuerstein, Smith Kline Beecham, King of Prussia, PA, for many conversations and helpful suggestions throughout the course of this work.

This work was supported in part by the National Institutes of Health Grants HL 28131 (T. B. Rogers) and HL 25675 and HL36974 (W. J. Lederer). Dr. Rogers is a recipient of a Research Career Development Award from the National Institutes of Health.

\section{References}

1. Benveniste, J., P. M. Henson, and C. G. Cochrane. 1972. Leukocyte-dependent histamine release from rabbit platelets: the role of IgE, basophils, and a platelet-activating factor. J. Exp. Med. 136:1356-1377.

2. Hanahan, D. J., and R. Kumar. 1987. Platelet-activating factor; chemical and biochemical characteristics. Prog. Lipid Res. 26:1-28.

3. Braquet, P., L. Touqui, T. Y. Shen, and B. B. Vargaftig. 1987. Perspectives in platelet-activating factor research. Pharmacol. Rev. 39:97-145.

4. Koltai, M., A. Tosaki, J.-M. Guillon, D. Hosford, and P. Braquet. 1989. PAF antagonists as potential therapeutic agents in cardiac anaphylaxis and myocardial ischemia. Cardiovasc. Drug Rev. 7:177-198.

5. Braquet, P., M. Paubert-Braquet, M. Koltai, R. Bourgain, F. Bussolino, and D. Hosford. 1989. Is there a case for PAF antagonists in the treatment of ischemic states? TIPS (Trends Pharmacol. Sci.). 10:23-30.

6. Handley, D. A. 1990. Preclinical and clinical pharmacology of platelet-activating factor receptor antagonists. Med. Res. Rev. 10:351-370.

7. Feuerstein, G. Z. 1989. PAF and the cardiovascular system. In Platelet-activating Factor and Human Disease. E. Barnes, editor. Blackwell Scientific Publications, Cambridge. 138-157.

8. Prescott, S. M., G. A. Zimmerman, and T. M. McIntyre. 1990. Platelet-activating factor. J. Biol. Chem. 265:17381-17384.

9. Montrucchio, G., G. Camussi, C. Tetta, G. Emanuelli, F. Orzan, L. Libero, and A. Brusca. 1986. Intravascular release of platelet-activating factor during atrial pacing. Lancet. ii:293.

10. Montrucchio, G., G. Alloatti, C. Tetta, R. De Luca, R. N. Saunders, G. Emanuelli, and G. Camussi. 1989. Release of platelet-activating factor from ischemic-reperfused rabbit heart. Am. J. Physiol. 256:H1236-1246.

11. Alloatti, G., G. Montrucchio, and G. Camussi. 1990. Prostacyclin inhibits the platelet-dependent effects of platelet-activating factor in the rabbit isolated heart. J. Cardiovasc. Pharmacol. 15:745-751.

12. Robertson, D. A., A. Genovese, and R. Levi. 1987. Negative inotropic effect of platelet-activating factor on human myocardium: a pharmacological study. J. Pharmacol. Exp. Ther. 243:834-839.

13. Robertson, D. A., D.-Y. Wang, C. O. Lee, and R. Levi. 1988. Negative inotropic effect of platelet-activating factor: association with a decrease in intracellular sodium activity. J. Pharmacol. Exp. Ther. 245:124-128.

14. Cohen, N. M., and W. J. Lederer. 1988. Changes in the calcium current of rat heart ventricular myocytes during development. J. Physiol. (Lond.). 406:115146.

15. Allen, I. S., N. M. Cohen, R. S. Dhallan, S. T. Gaa, W. J. Lederer, and T. B. Rogers. 1988. Angiotensin II increases spontaneous contractile frequency and stimulates calcium current in cultured neonatal rat heart myocytes: insights into underlying biochemical mechanisms. Circ. Res. 62:524-534.

16. Dosemeci, A., R. S. Dhallan, N. M. Cohen, W. J. Lederer, and T. B. Rogers. 1988. Phorbol ester increases calcium current and simulates the effects of angiotensin II on cultured neonatal rat heart myocytes. Circ. Res. 62:347-357.

17. Rogers, T. B., S. T. Gaa, C. Massey, and A. Dosemeci. 1990. Protein kinase $\mathrm{C}$ inhibits $\mathrm{Ca}^{2+}$ accumulation in cardiac sarcoplasmic reticulum. J. Biol. Chem. 265:4302-4308.

18. Kenzora, J. L., J. E. Perez, S. R. Bergmann, and L. G. Lange. 1984. Effects of acetyl glyceryl ether of phosphorylcholine (platelet-activating factor) on ventricular preload, afterload, and contractility in dogs. J. Clin. Invest. 74:1193-1203.

19. Levi, R., J. A. Burke, Z.-G. Guo, Y. Hattori, C. M. Hoppens, L. M. McManus, D. J. Hanahan, and R. N. Pinckard. 1984. Acetyl glyceryl ether phosphorylcholine (AGEPC) a putative mediator of cardiac anaphylaxis in the guinea pig. Circ. Res. 54:117-124.

20. Benveniste, J., C. Boullet, C. Brink, and C. Labat. 1983. The actions of Paf-acether (platelet-activating factor) on guinea-pig isolated heart preparations. Br. J. Pharmacol. 80:81-83.

21. Lepran, I., and A. M. Lefer. 1985. Ischemia aggravating effects of plateletactivating factor in acute myocardial ischemia. Basic Res. Cardiol. 80:135-141.

22. Stahl, G. L., Z.-I. Terashita, and A. M. Lefer. 1988. Role of platelet-activating factor in propagation of cardiac damage during myocardial ischemia. $J$. Pharmacol. Exp. Ther. 244:898-904.

23. Montrucchio, G., G. Alloatti, F. Mariano, R. de Paulis, A. Comino, G. Emanuelli, and G. Camussi. 1990. Role of platelet-activating factor in the reperfusion injury of rabbit ischemic heart. Am. J. Pathol. 137:71-83.

24. Yue, T.-L., M. Farhat, R. Rabinovici, P. Y. Perera, S. N. Vogel, and G. Feuerstein. 1990. Protective effect of BN 50739, a new platelet-activating factor antagonist, in endotoxin-treated rabbits. J. Pharmacol. Exp. Ther. 254:976-981.

25. Hwang S.-B. 1988. Identification of a second putative receptor of plateletactivating factor from human polymorphonuclear leukocytes. J. Biol. Chem 263:3225-3233.

26. Tahraoui, L., A. Floch, S. Mondot, and I. Cavero. 1988. High affinity specific binding sites for tritiated platelet-activating factor in canine platele membranes: counterparts of platelet-activating factor receptors mediating platelet aggregation. Mol. Pharmacol. 34:145-151.

27. Feuerstein, G., and J. M. Hallenbeck. 1987. Prostaglandins, leukotrienes, and platelet-activating factor in shock. Annu. Rev. Pharmacol. Toxicol. 27:301313.

28. Sybertz, E. J., R. W. Watkins, T. Baum, K. Pula, and M. Rivelli. 1985 Cardiac, coronary and peripheral vascular effects of acetyl glyceryl ether phosphoryl choline in the anesthetized dog. J. Pharmacol. Exp. Ther. 232:156-162.

29. Salari, H., V. Duronio, S. Howard, M. Demos, and S. L. Pelech. 1990. Translocation-independent activation of protein kinase $\mathbf{C}$ by platelet-activating factor, thrombin, and prostacyclin. Biochem. J. 267:689-696.

30. Vites, A.-M., and A. Pappano. 1990. Inositol 1,4,5-trisphosphate releases intracellular $\mathrm{Ca}^{2+}$ in permeabilized chick atria. Am. J. Physiol. (Heart Circ. Physiol.). 258:H1745-H1752.

31. Movsesian, M. A., A. P. Thomas, M. Selak, and J. R. Williamson. 1985. Inositol trisphosphate does not release $\mathrm{Ca}^{2+}$ from permeabilized cardiac myocytes and sarcoplasmic reticulum. FEBS (Fed. Eur. Biochem. Soc.) Lett. 185:328-332.

32. Nosek, T. N., M. F. Williams, S. T. Zeigler, and R. E. Godt. 1986. Inositol trisphosphate enhances calcium release in skinned cardiac and skeletal muscle. Am. J. Physiol. 250:C807-C811.

33. Capogrossi, M. C., T. Kaku, C. R. Filburn, D. J. Pelto, R. G. Hansford, H. A. Spurgeon, and E. G. Lakatta. 1990. Phorbol ester and dioctanoylglycerol stimulate membrane association of protein kinase $\mathrm{C}$ and have a negative inotropic effect mediated by changes in cytosolic $\mathrm{Ca}^{2+}$ in adult rat cardiac myocytes. Circ. Res. 66:1143-1155.

34. Yuan, S., F. A. Sunahara, and A. K. Sen. 1987. Tumor-promoting phorbol esters inhibit cardiac functions and induce redistribution of protein kinase $\mathrm{C}$ in perfused beating rat heart. Circ. Res. 61:372-378.

35. Gwathmey, J. K., and R. J. Hajiar. 1990. Effect of protein kinase C activation on sarcoplasmic reticulum function and apparent myofibrillar $\mathrm{Ca}^{2+}$ sensitivity in intact and skinned muscles from normal and diseased human myocardium. Circ. Res. 67:744-752.

36. Abdellatif, M., C. F. Neubauer, W. J. Lederer, and T. B. Rogers. 1991. Angiotensin-induced desensitization of the phosphoinositide pathway in cardiac cells occurs at the level of the receptor. Circ. Res. 69: 800-809. 